\title{
Comparative Analysis of Serum Mineral Levels and Parasite Load in Goats Naturally Infected with Gastrointestinal Nematodes
}

\section{Gastrointestinal Nematodlar ile Doğal Enfekte Keçilerde Parazit Yükü ile Serum Mineral}

\author{
Düzeylerinin Karşılaştırmalı Analizi
}

\author{
Serap Ünübol Aypak1, Süleyman Aypak², Hüseyin Voyvoda³, Gülşen Güven, Evrim Dereli Fidan', \\ Gamze Tosun1, Mehmet Gültekin³, Emrah Şimşek², Asude Gülçe Güler² \\ 'Department of Biochemistry, Adnan Menderes University School of Veterinary, Aydın, Turkey \\ 2Department of Parasitology, Adnan Menderes University School of Veterinary, Aydın, Turkey \\ ${ }^{3}$ Department of Internal Diseases, Adnan Menderes University School of Veterinary, Aydın, Turkey \\ ${ }^{4}$ Department of Chemistry, Adnan Menderes University School of Science and Literature, Aydın, Turkey \\ ${ }^{5}$ Department of Zootechnics, Adnan Menderes University School of Veterinary, Aydın, Turkey
}

\section{ABSTRACT}

Objective: This study aimed to investigate the relationship between serum mineral levels and parasite load in Saanen ( $n=37$ ) and Damascus ( $n=13)$ goats, which were all approximately 2 months pregnant and naturally infected with gastrointestinal nematodes.

Methods: To determine parasite concentration individually, fecal samples were taken from each goat, and the eggs per gram (EPG) of feces was detected via a modified McMaster technique. To investigate the possible effects of parasite concentration on serum mineral levels, blood was drawn from the goats and serum calcium, phosphorus, magnesium, iron, copper, zinc, manganese, nickel, and cadmium levels were measured via the ICP-OES technique.

Results: In a correlation analysis of the individual EPG values and mineral levels performed on the basis of the species, it was seen that increased egg numbers did not cause a statistically significant increase or decrease in Saanens except for cadmium (significant moderate positive correlation, $\mathrm{p}<0.05$ ) for both species. A comparison of the mineral element levels with the lower and upper normal limits in the published literature found that manganese and iron were below the normal range, while zinc and calcium levels were close to the lower limits. Conclusion: It is estimated that the effect of parasite load, which continuously increases with the progression of pregnancy and deliveries, on blood mineral levels would be much more significant.

Keywords: Damascus, gastrointestinal nematodes, goat, mineral, saanen

Received: 25.04.2016

Accepted: 29.06 .2016

\section{ÖZ}

Amaç: Bu çalışma gastrointestinal nematodlar ile doğal enfekte, 2 aylık gebe Saanen ( $n=37)$ ve Damascus $(n=13)$ keçilerinde, serum mineral düzeylerinin parazit yükü ile ilişkisini irdelemek amacıyla yapılmıştır.

Yöntemler: Parazit yoğunluğunun bireysel olarak belirlenmesi için her keçiden dışkı örneği alınarak modifiye McMaster tekniği ile gram dışkıdaki yumurta sayıları (EPG) belirlenmiştir. Parazit yoğunluğunun serum mineral düzeylerine olası etkilerini araştırmak için keçilerden kan örnekleri alınmış ve ICP-OES tekniği ile serumda kalsiyum, fosfor, magnesyum, demir, bakır, çinko, mangan, nikel, kadmiyum düzeyleri tespit edilmiştir. Bulgular: Irk düzeyinde bireysel EPG değerleri ile mineral düzeylerinin korelasyon analizlerinde; artan yumurta sayısının Saanen'lerde Kadmiyum hariç (pozitif yönde orta derecede önemli korelasyon, $\mathrm{P}<0.05$ ) her iki ırk için de istatistiki açıdan önemli bulunabilecek artış ya da azalmalara sebep olmadığı görülmüştür. Her iki ırk için tespit edilen mineral değer ortalamaları literatürlerde bildirilen alt ve üst sınır değerlere göre incelendiğinde mangan ve demirin normal değerlerin altında, bakır, çinko ve kalsiyumun alt sınır değerlere yakın olduğu tespit edilmiştir.

Sonuç: Gebeliğin ilerlemesi ve doğumlarla giderek artacak olan parazit yükünün kan mineral seviyelerine olan etkisinin çok daha belirgin olacağı tahmin edilmektedir.

Anahtar Kelimeler: Damascus, gastrointestinal nematod, keçi, mineral, saanen

Geliş Tarihi: 25.04.2016 Kabul Tarihi: 29.06.2016

This study has been presented at the $6^{\text {th }}$ National Veterinary Biochemistry and Clinical Biochemistry Congress (25-27.06.2013) and published in the summary pamphlet of the congress.

Bu çalışma, 6. Ulusal Biyokimya ve Klinik Biyokimya Kongresi'nde (25-27.06.2013) sunulmuş ve kongre özet kitapçı̆̆ında basılmıştır.

Address for Correspondence/ Yazışma Adresi: Dr. Süleyman Aypak E.mail: suleymanaypak@yahoo.com DOI: $10.5152 /$ tpd.2016.4758

(O) Copyright 2016 Turkish Society for Parasitology - Available online at www.tparazitolderg.org

OTelif hakkı 2016 Türkiye Parazitoloji Derneği - Makale metnine www.tparazitolderg.org web sayfasından ulaşılabilir. 


\section{INTRODUCTION}

The popularity of goat milk has increased, along with its consumption, because of its relative advantages noticed in recent years; goat breeding has accordingly gained relative importance within the livestock industry (1). The yearly comparison of the numbers involved in goat breeding also support this impression (4.9 million in 2009, 6.1 million in 2010, 7.1 million in 2011, and 8.1 million in 2012) (2). Gastrointestinal nematodes, whose presence in small ruminants may threaten the economic profitability of livestock breeding (3), have become a menace to goats keeping with the generalization of intensive breeding methods. Infection by such agents may cause loss of appetite, gastrointestinal dysfunction, and changes in protein, energy, and mineral metabolism, while changes in fluid balance may modify body composition and the quality of the animal's carcass (4). These infections, particularly those with a subclinical course, are generally neglected, causing a low-level, but persistent, loss of productivity. Even though this level of loss in productivity is not likely to be remarked at the individual level, loss of profit in the regional or national scale take place (5).

The Trichostrongyloidea and Strongyloidea superfamilies of worms, resident mainly in the abomasum as well as in the small and large intestine of ruminants, are extensive, with a large number of genera. The pathogenicity of these parasites in the various compartments of the gastrointestinal tract varies according to factors such as development and feeding patterns $(3,6,7)$. The effects of histologic pathology on blood chemistry also vary with the parasite type and concentration $(8,9)$.

Mineral elements are part of the constituents of many tissues; they also function as cofactors of different enzymes (1, 2, 10). Mineral deficiency delays growth, reduces productivity, and negatively affects the reproductive and immune systems of the animals $(3,4,10)$.

Digestion and absorption disorders due to endoparasites result in protein and trace element deficiencies in the host animal $(3,4$, 8). Mineral deficiencies related to malnutrition, in turn, lead to an impairment in immune function, thus unfavorably affecting the resistance to parasitic infections (11). The presence of mineral deficiencies may therefore result from parasitic infections, while they may also determine the severity of the infection.

Cadmium is a heavy metal that does not have any known essential function and is highly toxic. It leads to lipid peroxidation and glutathione consumption by binding to sulfhydryl groups in the tissues (particularly in the liver and the kidney). As a result, cell damage occurs (12). Simultaneously, cadmium inhibits antioxidant enzymes, such as catalase, manganese superoxide dismutase, and copper/zinc superoxide dismutase (13). Nickel is known to inhibit some enzymes at toxic levels in the same manner as cadmium (14). Nickel has not been proven as an essential element for animals, but the addition of nickel to their feed rations has been shown to have beneficial results (11). Due to their capacity to form free radicals, nickel and cadmium can cause inflammation, nucleic acid oxidation, and failure in the DNA repair mechanism. Mutagenic changes occur in cancer cases, which are induced by these elements (15).
In studies of the blood levels of hosts to parasitic infections, it has been shown that sheep experimentally infected with Trichostrongylus axei and T. colubriformis show a serious reduction in copper levels (16), while similarly severe deficiencies of copper and zinc are encountered in sheep naturally infected by Haemonchus contortus (17) and Trichostrongylus spp. (18) A positive correlation between iron level reduction with related anemias and the egg count per gram (EPG) of feces has been suggested $(17,19)$.

Parasites are living forms that are generally harmful to their hosts (6). It has been reported, however, that certain helminths protect their hosts from excessive heavy metal storage by keeping these metallic elements in their own bodies (20-22). Many trace elements (such as iron, copper, manganese, and molybdenum) are essential but are also heavy metals. Parasites are naturally expected to share all minerals absorbed through the host intestine. Following up on these considerations, our study aimed to examine the relationship between the serum levels of the macro-elements calcium, phosphorus, and magnesium and the micro-elements iron, copper, zinc, manganese, and the toxic heavy metals nickel and cadmium on the one side and the parasite load on the other.

\section{METHODS}

\section{Animals}

This study was planned as a follow-up to the clinical and laboratory evaluation of two goats of the Saanen breed brought from a company in the Izmir-Tire area to the Adnan Menderes University Veterinary School Internal Medicine Clinic due to their delayed growth, reduced food intake, and weight loss. It was reported that the enterprise where the goats came from, naturally infected by nematodes, had 37 Saanen and 13 Damascus breed, all of them 18 months old and two months pregnant. The two groups of goats had been obtained from different sites in Turkey (the Saanen breed from Foça, Izmir, and the Damascus from Adana).

\section{Examination of the feces}

Individual fecal samples were obtained by rectal examination and distributed over individual envelopes marked with the animals' earmark number. The strongyle-type EPG was determined in the absence of a genus-level or species-level diagnosis based on morphologic characteristics, and feces cultures were made. Cultivating was performed on a group basis for the Saanen and Damascus goats. To this purpose, the feces remaining after the individual egg counts were pooled by groups and thoroughly mixed. To facilitate development of the eggs to third-stage larvae, sawdust and water were mixed to a slurry-like consistency (3 parts feces to 1 part water), placed in the plastic containers, and then incubated at $26-28^{\circ} \mathrm{C}$ for one week (23-25). During this period, the samples were taken out of the incubator daily for airing by mixing; samples with a reduced water content were corrected. The larvae developing at the end of this period were collected by the Baermann-Wetzel method and diagnosed by morphologic criteria in accordance with the relevant publications $(26,27)$.

\section{Blood tests}

A $10 \mathrm{~mL}$ blood sample was collected from the jugular vein of each animal into gel serum tubes inscribed with the animal's 
earmark number. The blood samples were carried to the laboratory in cool transport bags. Serum was separated by centrifuging for $10 \mathrm{~min}$ at 3,000 rpm, then portioned and kept at $-20{ }^{\circ} \mathrm{C}$ until analyzed. To obtain protein precipitation before analysis, $4.5 \mathrm{~mL}$ $1 \mathrm{~N} \mathrm{HNO}_{3}$ was added to $0.5 \mathrm{~mL}$ of a serum sample, which was then homogenized and centrifuged for $15 \mathrm{~min}$ at 4,000 rpm. The supernatant was transferred to polyethylene tubes for analysis. Determinations were performed by Inductively Coupled Plasma/ Optical Emission Spectrometry (ICP-OES) for the calcium, magnesium, phosphorus, iron, copper, zinc, manganese, nickel, and cadmium levels for each of the two goat breeds.

\section{Statistical analysis}

The SPSS 15.0 statistical software package (SPSS Inc.; Chicago, IL, USA) was used for statistical treatment of the data. Comparisons between the Saanen and Damascus breeds for strongyle-type EPG counts and for the levels of mineral elements were done using the Student's t-test (28). Correlations of parasite density counts with the macro-elements (calcium, mag-

Table 1. Stool culturing results in goats

\begin{tabular}{|l|l|c|}
\hline Goat breeds & Parasite species & $\%$ \\
\hline Saanen & Haemonchus contortus & 67 \\
\cline { 2 - 3 } & Oesophagostomum spp. & 19 \\
\cline { 2 - 3 } & Trichostrongylus spp. & 8 \\
\cline { 2 - 3 } & Cooperia spp. & 3 \\
\cline { 2 - 3 } & Cooperia onchophora & 2 \\
\cline { 2 - 3 } & Ostertagia spp. & 1 \\
\hline \multirow{5}{*}{ Damascus } & Haemonchus contortus & 60 \\
\cline { 2 - 3 } & Cooperia onchophora & 20 \\
\cline { 2 - 3 } & Ostertagia spp. & 16 \\
\cline { 2 - 3 } & Cooperia spp. & 4 \\
\hline
\end{tabular}

nesium, and phosphorus) and the micro-elements (iron, copper, zinc, manganese, nickel, cadmium) were characterized by Pearson's correlation analysis (29).

Ethics committee approval was received for this study from the regional animal experiments ethics committee of Adnan Menderes University (Document no: 64583101-2014-009).

\section{RESULTS}

An EPG of 150-21,500 for the Saanen goats and 50-3,350 for the Damascus breed showed that both races were infected by varying measures (EPG grading: 0-1,000 mild, 1,000-2,000 moderate, $>2,000$ severe infection). Saanen goats were found to be more severely infected than the Damascus breed, with a statistically significant difference (strongyle-type EPG means 3,951.14 vs 903.33, respectively). Cultures pooled by the breed allowed diagnosing six different strains or genera in the Saanen and four in the Damascus goats (Table 1).

Comparison among the breeds of the mineral element levels showed slightly higher levels for five of nine parameters among the Damascus breed, but only the difference for calcium was statistically significant (Table 2). Comparison of the mineral element levels with the lower and upper normal limits indicated in the published literature found manganese and iron to be below the normal range, while zinc, copper, and calcium levels were close to the lower limits. A correlation between the EPG values and mineral element levels failed to show statistically significant differences, except for cadmium. Cadmium was in direct correlation with EPG $(p<0.05)$. No significant correlation was found between the nickel level in serum and the parasite level in feces (Figure 1-4).

\section{DISCUSSION}

Ruminants infected with nematodes have been reported to experience disorders of digestion and absorption, gastroenteri-

Tablo 2. The average macro-elements, micro-elements levels, and strongyle-type eggs per gram (EPG) of feces, according to Students t-test

\begin{tabular}{|c|c|c|c|c|}
\hline & Saanen $\bar{X} \pm S \bar{x}(n=37)$ & Damascus $\bar{X} \pm S \bar{x}(n=13)$ & Literature values & $\mathbf{t}$ \\
\hline Calcium (ppm) & $57.5 \pm 0.13^{b}$ & $60.3 \pm 0.06^{a}$ & 50-110 ppm & $-2.022^{\star}$ \\
\hline Magnesium (ppm) & $24.3 \pm 0.07$ & $25.1 \pm 0.06$ & 10-30 ppm & -0.815 \\
\hline Phosphor (ppm) & $61.85 \pm 4.12$ & $54.96 \pm 7.67$ & 35-90 ppm & $0.719-$ \\
\hline Iron (ppb) & $185.34 \pm 31.32$ & $172.81 \pm 48.97$ & $450-1900 \mathrm{pp}^{\mathrm{b}}$ & $0.216-$ \\
\hline Copper (ppb) & $564.37 \pm 32.83$ & $571.49 \pm 40.70$ & $500-1600 p^{b}$ & -0.136 \\
\hline Zinc (ppb) & $422.77 \pm 16.32$ & $406.13 \pm 32.01$ & $400-1600 \mathrm{pp}^{\mathrm{b}}$ & $0.463-$ \\
\hline Manganese (ppb) & $36.94 \pm 1.58$ & $33.90 \pm 3.53$ & $240-400 \mathrm{pp}^{\mathrm{b}}$ & $0.585-$ \\
\hline Nickel (ppb) & $59.53 \pm 1.12$ & $61.97 \pm 1.27$ & - & $-1.443-$ \\
\hline Cadmium (ppb) & $41.31 \pm 0.52$ & $45.28 \pm 2.03$ & - & $-1.894-$ \\
\hline Strongyle-type egg & $3951.14 \pm 686.15^{a}$ & $903.33 \pm 279.26^{b}$ & $\begin{array}{l}\text { Severity of the infection } \\
0-1000 \text { mild } 1000-2000 \\
\text { moderate } 2000 \text { - severe }\end{array}$ & $4.114^{\star \star *}$ \\
\hline
\end{tabular}




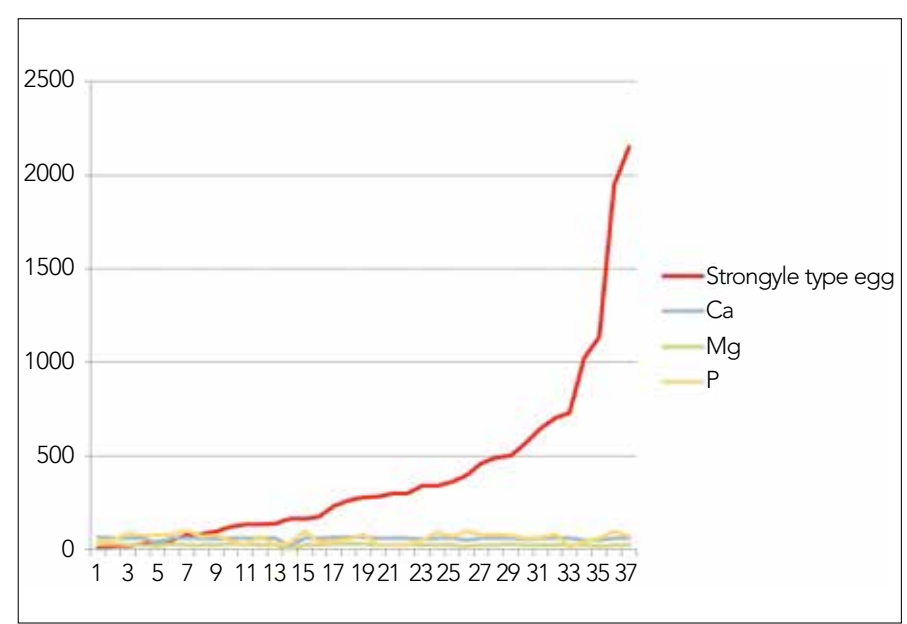

Figure 1. Comparison of the parasite density and macroelement levels in the individual Saanen goats $x$-axis: Goats ranked by increasing number of eggs

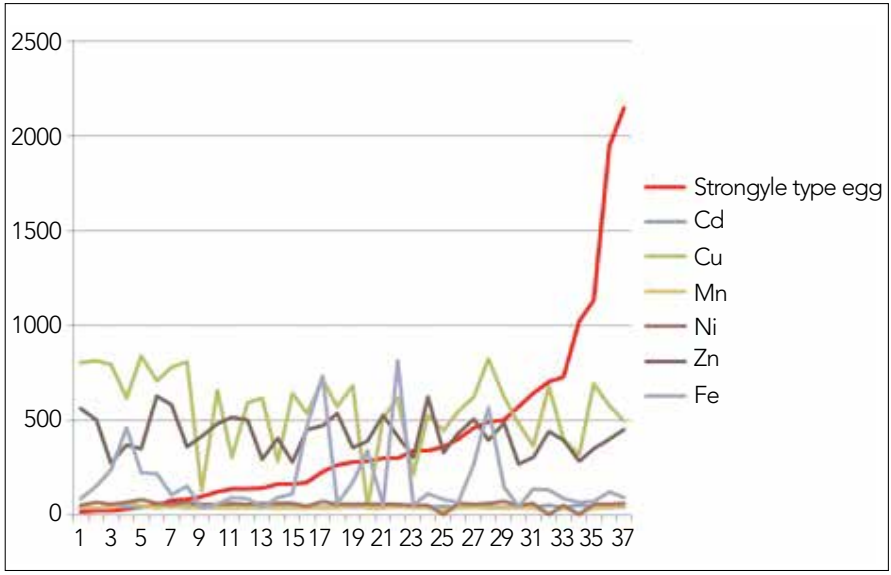

Figure 2. Comparison of the parasite density and microelement levels in the individual Saanen goats $x$-axis: goats ranked by increasing number of eggs

tis, loss of appetite, delayed growth, anemia, and productivity loss $(8,30-33)$. Similar findings were observed in the goats included in our study. There is no abundance effect on the blood mineral levels of these parasitoses, which otherwise would cause many undesirable physiologic and histologic effects. Only a limited number of studies have been performed so far in sheep; however, no available information exists for goats.

Ayaz et al. (9), in their study of sheep naturally infected by different endoparasites, examined different biochemistry values without finding any positive or negative difference from the controls in terms of calcium, phosphorus, and magnesium levels. Abdell (18) reported a fall in serum copper and zinc in sheep naturally infected with Trichostrongylus species. Silva et al. (17) similarly indicated low serum copper and zinc levels in sheep with spontaneous $H$. contortus infection. As for Hucker and Young (16), they noted a fall in plasma copper in sheep that they had infected with T. axei and T. colubriformis, and this fall was directly correlated with the EPG value. Symons (33) also found low plasma zinc levels in sheep experimentally infected with $T$. colubriformis. Özer et al. (34) reported low serum iron levels in lambs

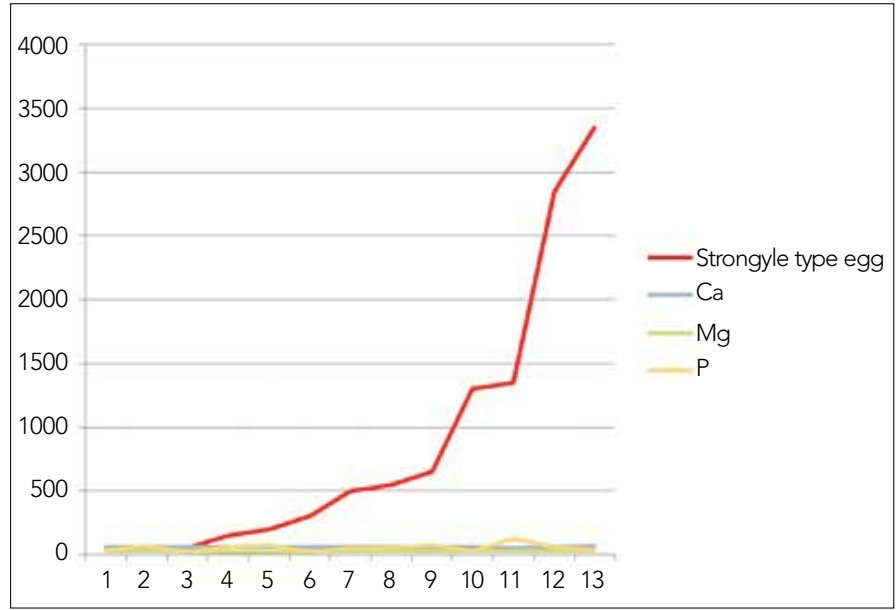

Figure 3. Comparison of the parasite density and macroelement levels in the individual Damascus goats

$x$-axis: goats ranked by increasing number of eggs

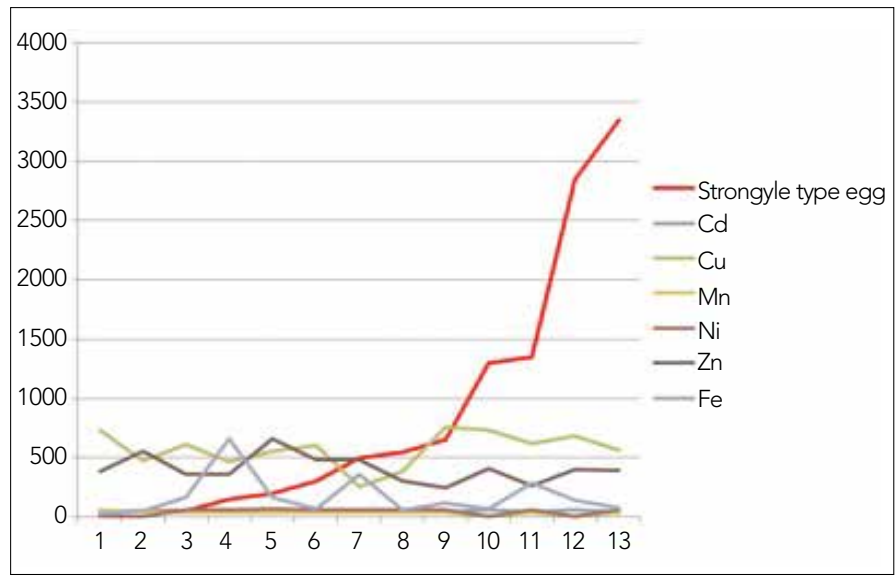

Figure 4. Comparison of the parasite density and microelement levels in the individual Damascus goats $x$-axis: goats ranked by increasing number of eggs

with gastrointestinal nematode infection; such low iron levels have also been signaled in sheep experimentally infected with $H$. contortus $(35,36)$. Similar findings of low serum iron were reported by Kolb et al. (37) in lambs with experimental T. colubriformis and $H$. contortus infections. Şahin and Akgül identified significantly reduced levels of plasma copper and zinc and serum iron in sheep with gastrointestinal nematode infection (8).

The fact that in our study serum iron was much lower than the lower normal value may be a result of the high proportion of anemia-causing parasites, mainly $H$. contortus, followed by Oesophagostomum spp. and Cooperia spp. identified in the animals (total percentages of anemia-causing parasites was $91 \%$ in the Saanen goats and $84 \%$ in the Damascus goats). In fact, important falls in the serum iron levels have been reported for both spontaneous and experimental $H$. contortus infections (19, 35-37).

The serum manganese levels in our study were found to be considerably inferior to the reference values; no published reports on manganese levels in parasitic infections could be identified. 
The closeness of the copper and zinc levels to the lower normal limits seems to parallel the reports on either spontaneous or provoked Trichostrongylus infections $(8,16,18)$. The intensification of this observation with advancing pregnancy suggests that the relative severity of parasitic infection very probably reduces the level of other minerals, in addition to copper and zinc.

No significant relationship could be identified between EPG and serum mineral element levels, except for cadmium, even in goats of the Saanen breed, which had been found to have moderate infection in seven cases and severe infection in 21. This led to speculation that herd history is important in determining the observability of different deficiencies due to different individual parasite loads in single animals. The application of anthelmintic agents, however infrequent and irregular in the case of this farm, may cause interruptions in the presence of parasites in the animals, thus allowing for a recovery in serum mineral levels.

Interestingly, the presence of cadmium, a toxic heavy metal, in the animals in our study, had a direct, moderately strong correlation to the fecal EPG. It has been reported that while parasites may help detoxify the host organism by accumulating heavy metals in their own bodies, they may also disrupt the host's detoxification capacity $(20,38,39)$. It has also been observed that cadmium exposure depresses the immune system and that parasite infections progress with greater severity in immune-depressed goats (40). The direct correlation observed in our study between infection severity and cadmium levels may result from either of these mechanisms.

For nickel, while its role as an essential element has not been established, some animal studies have shown positive results from the addition of nickel to food rations (11). Its role in the digestive process has not yet been elucidated, and no relationship was identified in our study between its presence and the parasite load.

The different levels of mineral elements among the different breeds of animals are thought to be due to either the parasite load or to some physiological variations of the breeds.

\section{CONCLUSION}

In conclusion, no significant relationships between parasite load and serum mineral levels could be detected in our study, except for cadmium. We speculated that the anthelmintic interventions performed, albeit sporadic, mitigated the adverse effects of parasitosis on serum mineral levels.

Another observation was the low average iron levels, well below the lower normal limit, for both breeds. We attribute this to the part played by the overwhelming preponderance of $\mathrm{H}$. contortus among the parasites present in the goats. This organism, which stands out due to its pathogenicity, represents a major cause of parasitosis anemia and requires special attention in measures against the disease.

The predictable increase in parasite load, along with the progress in pregnancy and the following deliveries, is expected to have a more marked effect on the blood levels of the mineral elements.
Ethics Commitee Approval: Ethics committee approval was received for this study from the regional animal experiments ethics committee of Adnan Menderes University (Document no: 64583101-2014-009).

Peer-review: Externally peer-reviewed.

Author Contributions: Concept - S.Ü.A., S.A., H.V; Design - S.Ü.A., S.A., H.V.; Supervision - S.Ü.A., S.A.; Funding - S.Ü.A., S.A., H.V., G.G.; Data Collection and/or Processing- S.A., M.G., E.Ş., S.Ü.A, G.G., E.D.F., G.T., A.G.G.; Analysis and/or Interpretation - S.Ü.A., S.A.; Literature Review S.Ü.A., S.A. ; Writing - S.Ü.A., S.A.; Critical Review - S.Ü.A., S.A.

Conflict of Interest: No conflict of interest was declared by the authors.

Financial Disclosure: This study wasn't supported.

Etik Komite Onayı: Bu çalışma Adnan Menderes Üniversitesi Hayvan Deneyleri Yerel Etik Komitesi'nin 64583101-2014-009 nolu onayı ile yapılmıştır.

\section{Hakem değerlendirmesi: Dış bağımsız.}

Yazar Katkıları: Fikir - S.Ü.A., S.A., H.V.; Tasarım - S.Ü.A., S.A., H.V.; Denetleme - S.Ü.A., S.A.; Kaynaklar - S.Ü.A., S.A., H.V., G.G.; Veri toplanması ve/veya işlemeşi - S.A., M.G., E.Ş., S.Ü.A, G.G., E.D.F., G.T., A.G.G.; Analiz ve/veya yorum - S.Ü.A., S.A.; Literatür taraması - S.Ü.A., S.A.; Yazıyı yazan - S.Ü.A., S.A.; Eleştirel Innceleme - S.Ü.A., S.A

Çıkar Çatışması: Yazarlar çıkar çatışması bildirmemişlerdir.

Finansal Destek: Bu çalışmada herhangi bir destek alınmamıştır.

\section{REFERENCES}

1. Anne Sütüne En Yakın Süt Hayvan Sütü Hangisidir-Keçi Sütü Yararları. Available from: URL: http://www.sagligimiza.com/tag/keci-sutu-faydalari, date of access: 22.11.2016.

2. Türkiye İstatistik Kurumu, Available from: URL: www.tuik.gov.tr/PrelstatistikTablo.do?istab_id=682, date of access: 22.11.2013.

3. Guralp N. Helmintoloji. 2 th Edition. Ankara, Ankara Üniversitesi Basımevi; 1981.

4. Fox MT. Pathophysiology of infection with gastrointestinal nematodes in domestic ruminants: recent developments. Vet Parasitol 1997; 72: 285-308. [CrossRef]

5. Aypak, S. Mide Bağırsak Nematodları, Sığır ve Koyunlarda Paraziter Hastalıklar Özel Sayısı. Turkiye Klinikleri J Vet Sci 2012; 3: 97-102.

6. Toparlak M, Tuzer E. Veteriner Helmintoloji. 3 th ed. 81-159, i.Ü. Veteriner Fakültesi Masaüstü Yayımcılık Ünitesi, İstanbul, 2000.

7. Umur Ş, Koroğlu E, Guçlü F, Tınar R. Nematoda. In, Tınar R (Ed): Helmintoloji. 1 th ed. 1-102, Nobel Yayın Dağıtım, Ankara, 2006.

8. Sahin T, Akgul Y. Endoparazitli Koyunlarda Bazı İz Element ve Biyokimyasal Parametrelerin Seviyeleri Üzerine Araştırmalar. Yüzüncü YıI Üniv Sağ Bil Derg 2006; 9: 100-6.

9. Ayaz E, Ertekin A, Ozdal N, Tas Z. Endoparazitli (Fasciola spp., Dicrocoelium dendriticum, Kist Hidatik, Trichostrongylidae ve Protostrongylidae) Koyunlarda Bazı Biyokimyasal Parametreler. T Parasitol Derg 2006; 30: 57-64.

10. Erdoğan $S$, Ergün $Y$, Erdoğan $Z$, Kontas T. Hatay bölgesinde yetiştirilen koyun ve keçi serumlarında bazı mineral madde düzeyleri. Tük J Vet Anim Sci 2002; 26: 177-82.

11. McClure S J. How minerals may influence the development and expression of immunity to endoparasites in livestock. Parasite immunol 2008; 30: 89-100.

12. Ercal N, Gurer OH, Aykın BN. Toxic metals and oxidative stress part I: mechanisms involved in metal-induced oxidative damage. Curr Top Med Chem 2001; 1: 529-39. [CrossRef] 
13. Casalino E, Calzaretti G, Sblano C, Landriscina C. Molecular inhibitory mechanisms of antioxidant enzymes in rat liver and kidney by cadmium. Toxicology 2002; 179: 37-50. [CrossRef]

14. Das KK, Das SN, Dhundasi SA. Nickel, its adverse health effects \& oxidative stress. Indian J Med Res 2008; 128: 412-25.

15. Dong W, Simeonova PP, Gallucci R, Matheson J, Flood L, Wang S, et al. Toxic metals stimulate inflammatory cytokines in hepatocytes through oxidative stress mechanisms. TAAP 1998; 151: 359-66. [CrossRef]

16. Hucker DA, Yong WK. Effects of concurrent copper deficiency and gastro-intestinal nematodiasis on circulating copper and protein levels, liver copper and bodyweight in sheep. Vet Parasitol 1986; 19: 67-76. [CrossRef]

17. Silva RM, Ferreıra-Neto JM, Sampaı IBM. The influence of diet and gastrointestinal parasites on serum copper and zinc in sheep (Abst). Arq Esc Vet Univ Minas Gerais, 1978; 30: 261-74.

18. Abdell All TS. Haematological and biochemical studies on the efficacy of synanthic againts gastrointestinal parasites in sheep. Assiut Vet Med J 24 (48): 197-203.

19. Siddiqua A, Mannan MA, Hussain MA. Some biochemical studies in the blood of goats naturally infected with intestinal parasites. Ind Vet J 1989; 66: 502-4.

20. Beskaya A, Yıldız, K, Basalan M, Us FM. Kırıkkalede endüstri bölgesi civarında toprak, yem ve bu yörede yetiştirilen koyunlar ile parazitlerinde bazı ağır metallerin belirlenmesi. Etlik Vet Mikrobiol Derg 2008; 19: 39-46.

21. Sures B Siddal R. Pomphorynchus laevis: The intestinal Acantocephalan as a lead sink for its fish host, chub. Exp Parasitol 1999; 93: 66-72. [CrossRef]

22. Sures B, Siddal R. Taraschewski H. Parasites as accumulation indicators of heavy metal pollution. Parasitol Today 1999; 15: 16-21. [CrossRef]

23. MAFF. Manual of Veterinary Parasitological Laboratory Techniques Reference Book Vol. 418, 3th ed. pp. 159, Ministry of Agriculture, HMSO, London, 1986.

24. Stoye M. Parasitologische laboruntersuchungen in der praxis. Prakt Tierarzt 1984; 65: 132-136.

25. Thienpont D, Rochette F, Vanparijs OFL. Diagnosing Helminthiasis by Coprological Examination. Janssen Research Foundation, Beerse, 1979.

26. Van Wyk JA, Cabaret J, Michael LM. Morphological identification of nematode larvae of small ruminants and cattle simplified. Vet Parasitol 2004; 119: 277-306. [CrossRef]
27. Senlik B. Teşhis Yöntemleri. In. Tınar R (Ed): Helmintoloji. 1 th ed. 463-535, Nobel Yayın Dağıtım, Ankara, 2006.

28. Kutsal A, Alpan O, Arpacık R. İstatistik uygulamalar. Bizim Büro Basımevi, Ankara, 1990.

29. Sümbüloğlu K, Sümbüloğlu V. Biyoistatistik. Özdemir Yayıncılık, Ankara, 1993.

30. Doganay A. Paraziter hastalıklardan ileri gelen ekonomik kayıplar. Vet Hek Dern Derg 1993; 64: 52-9.

31. Ozkoç U. Nematod invazyonları, Koyun-Keçi Hastalıkları ve Yetiştiriciliği 1. Baskı, 235-252, Tüm-Vet Hayvancılık İşletmeleri Yayını. İstanbul, 1990

32. Dunn MA. Veterinary Helmintology. Second edition, William Heinemann Medical Books Ltd., London, 1978.

33. Symons LEA. Plasma zinc innapetencein sheep infected with Trichostrongylus colubriformis. J. Comparative Patho 1983; 93: 547-50. [CrossRef]

34. Ozer E, Yılmaz K, Erkal N, Saki CE, Turhan T, Angın M, et al. Bazı eimeria türleri ile deneyssel olarak enfekte edilen erkek Akkaraman kuzularında demir ve demir bağlama kapasitesi. FÜ Saglik Bil Derg 1995; 2: 245-57.

35. Silverman PH, Mansfield ME, Scott HL. Haemonchus contortus Infection in sheep: Effect of various levels of primary infections on nontreated lambs. Am J Vet Re 1970; 31: 841-57.

36. Albers GAA, Gray GD, Le Jambre LF, Barger IA, Barker JSF. The effect of Haemonchus contortus infection on haematological parameters in young merino sheep and its significance productivity. Ani Prod 1990; 50: 99-100. [CrossRef]

37. Kolb E, Rehbein S, Ribbeck R, Alavad A, Leo M, Siebert P. Das verhalten hamatologischer parameter und klinisch-chemischer kennwerte im plasma sowie der gehalt an ascorbinsaure in leber, milz und nebenieren bei gesunden und bei mit Haemonchus contortus und trichostrongylus colubriformis. Infizierten Lammern, Berliner und Münchener Tierarzliche Wochenschrift. 1993: 12: 411-8.

38. Gismondi E, Rigaud T, Beisel JN, Leguille CC. Microsporidia parasites disrupt the responces to cadmium exposurein a gammarid. Environ Pollut 2012; 160: 17-23. [CrossRef]

39. Sures $B$, Radzuweit $H$. Pollution induced heat schock protein expression in the amphipod Gammarus roeseli is affected by larvae of Polymorphus minitus (Acantocephala). J Helminthol 2007; 81: 191-7. [CrossRef]

40. Bernhoft RA. Cadmium toxicity and treatment. Sci World J 2013. doi: 10.1155/2013/394652 [Epub ahead of print]. [CrossRef] 